\title{
The Barriers to Selecting Optimal Economic Policy in South Korea
}

Jude Abeyeratne, Kohei Tsukada, Rohan Sheth, Ronak Thakore \& Siddharth Patel

\begin{abstract}
Introduction
Four of the largest conglomerates in South Korea are Samsung Group, Hyundai-KIA Automotive Group, LG Group and SK Telecom. In 2009, the joint market value of the assets these conglomerates owned amounted to around half of the South Korean GDP (Wang 2010). Ostensibly, the South Korean economy is dominated by the conglomerates. Samsung and LG are the two major players in Korea's electronics industry; Hyundai and KIA are the two major players in the automotive industry.

The export dependency (Total Exports/GDP) of South Korea is $44.9 \%$ and its import dependency (Total Imports/GDP) is 38\% (CIA 2010). This indicates that the South Korean economy is highly dependent on global trade as well as on the conglomerates. It has signed a Free Trade Agreement (FTA) with the European Union and will ratify FTAs with some of its other trading partners such as China, United States, Japan and Australia (YONHAP News Agency 2010a). It is our view that such changes in trade policy are supported by the conglomerates, which have considerable sway over the government, due to their significant contributions to the economy.

The purpose of this paper is to analyse the source and the nature of the impediments the government faces in implementing policies that enable freer trade in South Korea. We do this from the perspective of President Lee Myun-bak, who we characterise as a key veto player, as he draws political support from groups that have conflicting agendas.
\end{abstract}




\section{Analysis}

Our analysis in this section is based on employing the theoretical ideas of New Trade theory to assess the trade realities in South Korea, a two-level game to characterise its political economy constraints pertaining to altering trade-related policies and finally, the determinacy paradox to suggest the mechanism which suggests why the overall situation often appears resistant to change.

South Korea's post-War economic growth can arguably be attributed to the application of the New Trade theory, which argues in favour of more protectionist policies in favour of key industries especially during the earlier phases of their development. Using the channel, the government was able to increase their economic competitiveness and dramatically improved GDP. It is reasonable to assume that, more recently, in the face of increasing trade competition from other developing countries in the region, the ratification of FTAs with some of its key trading partners would enable South Korea to entrench its trade ties and ensure economic growth into the future.

However, in attempting to propose and successfully ratify FTAs, the President ends up facing a dilemma, which we will characterise below as a two-level game. Essentially, he needs to satisfy the minority electorate that supports the government's initiatives on trade-related policies at the international level, while placating the majority electorate that wants the government to focus on more protectionist domestic policies instead. This leads him into an impasse; he cannot select the best policy that satisfies both groups, hence creating what can be described as a determinacy paradox.

\section{New Trade Theory}

The New Trade theory suggests subsidising and protecting certain domestic industries from foreign competition in order to develop their competitive advantage in the global market (Krugman 1992). For instance, the government encouraged the growth of conglomerates and made large domestic mergers \& acquisitions (M\&A) transactions, putting a high priority particularly on the manufacturing and finance industries (Kim \& 
Paul 2009). South Korea's shipbuilding and electronics industries have famously received subsidies from the government in the past (Kelly-Garrison 2009).

As M\&A led to larger oligopolies, the conglomerates had more capital available to exploit scale economies, including developing new technologies, than they would have had in a highly competitive domestic market. The resulting large domestic electronics and automobile firms were encouraged to compete with their international rivals.

This led to the creation of a two-tier economy, where the first-tier, consisting of large conglomerates, experienced dramatic growth, while the second-tier, consisting of smaller businesses and ordinary people, struggled to make ends meet. In fact, the first tier often grew at the detriment of the second tier. For instance, in order to be price competitive on a global scale, the conglomerates prevented their subcontractors from hiking their production costs (Lee 2010a). As a result, a conflict brewed between the conglomerates and the small businesses, creating an impediment for the government's intensive exportoriented trade strategy.

\section{Two-Level Game}

The dilemma that the South Korean government increasingly faced in trying to appease the supporters of both levels that characterise the economy can usefully be illustrated as a twolevel game (Putnam 1988).

The source of the dilemma, which forms the basis of the two levels in the game, is simple. Smaller firms that had a focus primarily at the national level demand their government create policies that work in their favour. The conglomerates and the politicians that they actively supported had a more international focus, demanding that the government satisfy their needs contrary to the demands of smaller domestic firms. 
TABLE 1: PROFITS MADE UNDER COMBINATIONS OF DIFFERENT TRADING POLICIES

\begin{tabular}{|c|c|c|c|}
\hline & & \multicolumn{2}{|c|}{ European Union } \\
\hline \multirow{3}{*}{ 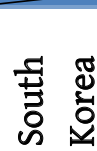 } & & Free Trade & Protectionism \\
\hline & Free Trade & 800,800 & 100,1000 \\
\hline & Protectionism & 1000,100 & 200,200 \\
\hline
\end{tabular}

Table 1 illustrates the political "prisoner's dilemma" in a two-level game situation using the example of South Korea and the European Union and the possible strategies of freer trade or protectionism. In a one-off or short-term game South Korea would be better off pursuing protectionism, regardless of the policy the EU pursues; likewise, the same is true for the EU too. Smaller domestic firms, and a President trying to seek short-term favour, would arguably favour this solution. Consequently, the game results in a Nash equilibrium where both countries would select protectionist policies, regardless of the fact that free trade is a superior strategy.

The game is resolved by realising that players at the international level usually have a longer-term focus. Conglomerates such as Samsung or Hyundai naturally have a longerterm perspective than a locally operated firm might have. Similarly, both countries are also better off in the longer run if each continues to play free trade. Therefore, at the international level, the South Korean President, if he were representing the country, would endorse an FTA and the conglomerates would support his decision, albeit at the expense of the small businesses. Since the president can have incentives that are aligned with either small domestic firms or the conglomerates depending on his horizon in making decisions, he faces a dilemma.

At the national level, free trade does not appeal to small businesses, who endorse protectionism, at the expense of the conglomerates. Since free trade is likely to expose them to the risk of higher competition from foreign rivals in the domestic market, their 
competitiveness may not be adequate to ensure their survival. It is therefore unsurprising that the President is planning to ratify FTAs with the US, China and Japan, but cannot do it so smoothly with the two conflicting agendas.

\section{Determinacy Paradox in Free Trade}

According to Bhagwati, this impasse is not uncommon when considering the political economy of trade policy. He proposes the determinacy paradox, which is a concept that relates to the observation that a given outcome cannot be altered unless the entity responsible for doing so has control over all the variables that it is dependent on (Bhagwati 1989). In the case of the South Korean trade policy, there are many variables, as outlined below, that the President cannot possibly control.

Consider the fact that, according to the Big Mac Index as of $21^{\text {st }}$ July 2010 (The Economist 2010), the South Korean currency was undervalued by about 25\%. Exporters could therefore gain a competitive advantage compared to other countries with relatively overvalued currencies. Naturally, because of this, importing become more costly, creating inflationary pressures. The price of imported goods indeed inflated by 11.3\% from May 2009 to May 2010 (YONHAP News Agency 2010b) and the price of agricultural products leapt 16.1\% from July 2009 to July 2010 (Kim 2010). A key reason for the inflation is South Korea's low food selfsufficiency rate of 49\% as of 2006 (Kwon 2010). The high dependency on food supply from other countries brings a risk of inflation in the case of a reduction in the international food supply.

The real jobless rate has also been increasing rapidly, hitting $10.35 \%$ in January 2010 (Lee 2010b). The government expected the conglomerates to create job opportunities through their market share expansion in the global market. However, this has not been successful, leading to increased criticism against the government.

There are many negative opinions and protests against FTAs with the US, China and other countries, as it may cause devastating damage to South Korean farmers and light manufacturing industries (Chosun Ilbo 2010). It would be hard for South Korean farmers to 
compete with Chinese and American competitors who have stronger price competitive advantages.

The conglomerates represent the minority of voters who support FTAs and the government, as they have gained a price competitive advantage and made record profits through the undervalued currencies and subsidies. By contrast, farmers and small businesses, the majority of voters, criticise the FTAs and President, as they are suffering from high inflation of imported goods due to the weak currency and high unemployment rates.

The two conflicting groups and the factors that affect them are externalities that take away degrees of freedom from the South Korean President and get in the way of him implementing free trade policies. Implementing an unpopular policy could lead him to lose the re-election. Therefore, in order to stay in power, he would need to shift his policies to favour the smaller businesses and farmers who represent the majority of the electorate.

\section{A Look Ahead}

In light of this situation and our analysis, we conclude with the following as a resolution to the seemingly irremediable problem we have outlined in this paper that could help the President to reduce the conflict between the two factions in the economy.

The President could subsidise small businesses and farmers so that subcontractors to the conglomerates can still provide competitive prices to them, and farmers would be able to raise the country's food self-sufficiency rate, which would then ease the food price inflation. These subsidies could partly be financed by retracting them gradually from the conglomerates. Since they are no longer infant industries, their subsidies should ideally be scaled downwards anyway. 


\section{References}

- Bhagwati, J 1989, 'Is free trade passé after all?', Review of World Economics, vol. 125, no. 1, pp. 17-44.

- Chosun Ilbo 2010, FTA with China Should Aim at Asian Economic Integration retrieved 26th July 2010, <http://english.chosun.com/site/data/html_dir/2010/04/22/2010042201186.html>.

- CIA 2010, CIA The World Factbook, retrieved 25th July 2010, <https://www.cia.gov/library/publications/the-world-factbook/index.html>.

- Kelly-Garrison, S 2009, 'A Sword and a Shield: South Korea's Strategic Use of World Trade Organization Litigation', Journal of Asia-Pacific Business, vol. 10, no. 2, pp. 18699.

- Kim, CJ 2010, Food inflation spike alarms policymakers, The Korea Herald, retrieved Aug 20th 2010, <http://www.koreaherald.com/national/Detail.jsp?newsMLId=20100805000815>.

- Kim, H \& Paul, DB 2009, 'The Management Characteristics of Korean Chaebols vs. non-Chaebols: Differences in Leverage and its Ramifications: Myth or Reality?', Advances in Management, vol. 2, no. 11, pp. 26-35.

- Krugman, P 1992, 'Does the new trade theory require a new trade policy?', World Economy, vol. 15, no. 4, pp. 423-42.

- Kwon, S-t 2010, Russia-induced Agflation The Dong-A Ilbo, retrieved Aug 25th 2010, $<$ http://english.donga.com/srv/service.php3?biid=2010080932948>.

- Lee, C-s 2010a, Tale of two economies in Korea, The Korea Times, retrieved 8th Sep 2010, <http://www.koreatimes.co.kr/www/news/opinon/2010/07/137_70395.html>.

- Lee, H-s 2010b, Real Unemployment Rate Hits 10.36\%, The Korea Times, retrieved 25th July 2010, <http://www.koreatimes.co.kr/www/news/biz/2010/03/123_62389.html>. 